\title{
DISTANT THUNDER Romance of the Fossiles
}

\section{Geologist and science writer Nina Morgan contemplates the role of love in the development of geology}

It is often said that behind the success of every man stands the love of a good woman, and this is certainly true for many geologists. Wives, including Emma Darwin, Mary Buckland, Charlotte Murchison, Mary Lyell and sisters, such as Anne Phillips, all played important roles in furthering the science of geology. But for John Hailstone [17591847], sixth Woodwardian professor of geology at Cambridge University, the course of 'love' was convoluted, to say the least.

\section{Fossile legacy}

Hailstone was born in Hoxton near London on 15 December 1759, and went up to Cambridge in 1778 . He was elected Fellow of Trinity College in 1784, and in 1788 became the sixth Woodwardian Professor of Geology.

The Woodwardian Professorship was established in 1728 under the title 'Professor of Fossils', thanks to a generous bequest from John Woodward [1665-1728]. Woodward, a brilliant scholar who dabbled in a wide range of fields was perhaps the first academic to fully appreciate the importance of field work in geological studies. He is also thought to have served as the inspiration behind the cuckolded Dr Fossile in Three hours after Marriage, a restoration comedy attributed to John Gay [1685-1732].

Early on in his career as Woodwardian Professor, Hailstone travelled to Freiburg in Germany to study with Adolph Gottlob Werner [1749-1817], the most famous teacher of geology and mineralogy of the day. In 1792, soon after his return, he published a Plan of a Course of Lectures, which may be the earliest prospectus for geological teaching in a British University. In 1814 he went on to compile the Outline Geology of Cambridgeshire, the first account of the geology of Cambridgeshire. Although he doesn't appear to have given many lectures on geology, Hailstone did build up a collection of rocks and minerals to supplement Woodward's mainly fossil collection. He was elected to the Royal Society in 1807, and the same year became a member of the Geological Society.

Although the salary attached to the Woodwardian Professorship was not particularly generous-just £100 a year-it offered many advantages in terms of light workload, academic freedom and few, if any, teaching commitments. But there were drawbacks. One of the conditions of Woodward's will was that the holder of the post should not be distracted by matrimony.

Thus, Hailstone's career as Woodwardian Professor came to a grinding halt when, at the age of 58 , he married 35-year-old Mary Telford [17831838] in York on 21 May 1818. It might have been love, but the motive behind his marriage is not obvious. Hailstone may not have taken the Woodwardian requirement for celibacy too seriouslyafter his death it was rumoured that he fathered four illegitimate children. But he seems to have been content with the way things turned out. He retired to the vicarage of Trumpington near Cambridge, worked for the education of the poor of his parish, and continued his studies in chemistry, mineralogy and geology.

\section{Marriage of the mind}

But a love match or not, Hailstone's marriage did play an important role in the development of geology. When, early in the Lent Term of 1818 , rumours began to spread around Cambridge that Hailstone was proposing to marry-and thus create a vacancy for the Woodwardian ProfessorshipAdam Sedgwick [1785-1873], then an
Assistant Tutor bored with teaching mathematics to indifferent Cambridge undergraduates and longing for outdoor activity and "active exertion in a way which will promote my intellectual improvement", decided to apply. "I had", Sedgwick recalled, slightly tonguein-cheek, "but one rival, Gorham of Queen's, and he had not the slightest chance against me for I knew absolutely nothing about geology, whereas he knew a great deal - but it was all wrong."

Sedgwick got the job, but his victory came at some personal cost. He took his Woodardian 'marriage vows' seriously and often wrote wistfully about his lack of wife and children, noting that "...my Museum is in the place of wife and children."

End notes: Sources for this vignette include the entry for John Hailstone by John. D. Pickles in the DNB; Adam Sedgwick, Geologist and Dalesman by Colin Speakman (ISBN 978-0-99556094-9); The life and letters of Adam Sedgwick by JW Clark and TM Hughes, first published in 1890 and available online at Archive.org; The bicentenary of a pioneering account of the Geology of Cambridgeshire by Douglas Palmer available at https://www.esc.cam.ac.uk; and the Dalesman Don by Douglas Palmer, Geoscientist May 2018, pp. 17-19.

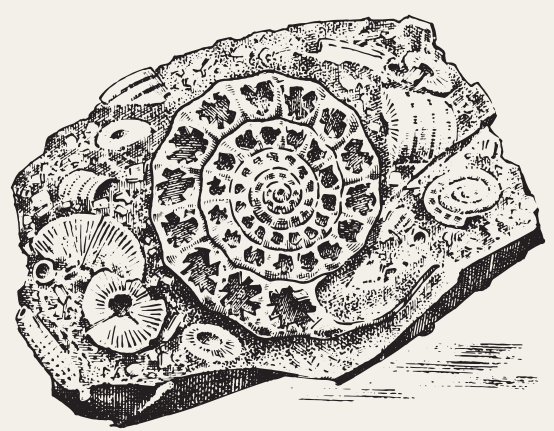

* Nina Morgan is a geologist and science writer based near Oxford. Her latest book, The Geology of Oxford Gravestones, is available via www.gravestonegeology.uk 